\section{IDENTIFICATION OF TIMBERS}

$\mathrm{T}$ WO leaflets have recently been issued under the auspices of the Department of Scientific and Industrial Research by the Forest Products Research Laboratory, Princes Risborough: No. 34 on "The Identification of Timbers", and No. 37 on "Selecting Ash by Inspection" (H.M. Stationery Office, London, 1944). Leaflet No. 34 is intended to be a rough-andready guide to the identification of timbers. Its aim is the temporary one of taking the place of more elaborate text-books and official publications at present practically unobtainable. As is well known, owing to the demands of the War, a number of new. or at least unfamiliar timbers are being used in Great Britain, and it is at times difficult for those wishing to do so to identify timbers the use of which is permitted by official specifications. General appearance, colour, texture, weight and smell, etc., are useful aids to the cognoscenti, but more reliable tests are based on the characteristic structural features remaining unaltered under conditions which may entirely change the external appearance of the timber. The object of the leaflet is to describe and illustrate the principal structural features of wood and to explain how they can be used in identifying timbers in the factory or office with the minimum of apparatus and little or no previous experience.

The text first describes the type of sample required and its method of preparation for examination, the sample being of a size convenient for handling. Details are then given of the structure of wood, heartwood and sapwood, softwoods (conifers) and hardwoods, structural features of softwoods and the same of the hardwoods. Two tables descriptive of the chief features of certain species are given, one for softwoods (larch, Scots pine, Douglas, western hemlock, spruce, noble fir, western red cedar and Parana pine) and the other for hardwoods (oak, sweet chestnut, ash, elm, beech, birch and sycamore). Two plates show photographs of cross-sections (magnified $\times 10$ ) of some of the species mentioned above.

Leaflet No. 37 deals with ash. The importance of ash depends largely on its mechanical properties, notably its toughness, high resistance to shock and the readiness with which it can be shaped by steam and bending. These properties are subject to considerable variation, and it is of importance to users that they should be able to judge the quality of the timber whether in the standing tree or in the conversion thereof. Mechanical testing has various inherent and obvious drawbacks, and in any event involves standardized equipment and the waste of $a^{c}$ considerable proportion of the timber. It is therefore usually necessary to fall back on visual methods of inspection and other simple tests.

The investigations dealt with in the leaflet are made on English ash (Fraxinus excelsior), but generally they cover other kinds of ash commonly imported into the United Kingdom, the Fraxinus excelsior of Continental Europe and the American ash (various species of Fraxinus). Shippers usually allude to American ash as 'tough ash' or 'cabinet ash'. The better grades of the former are suitable, or at any rate are used, for many of the same purposes as well-grown English ash, and are widely used in normal times by the automobile and agricultural implement industries, most of the good ash in Britain having been hunted down and felled during the War of 1914-18.

The leaflet discusses this matter of selection of ash by inspection under the headings of factors affecting the quality of the timber, structure as an indication of quality, density, selection of standing timber and winter- and summer-felled timber. As regards selection, trees with a good length of straight clean bole, clear of side-branches and with a well-developed healthy crown at least one half the height of the tree should be chosen. Such trees are likely to be found in fairly open woodland and are preferable to those grown in crowded woods. The prejudice against summer-felled timbers, the writer says, is mainly due to the fact that weather conditions in summer favour the occurrence of splits and checks owing to too rapid drying. Provided that the logs can be taken to some spot where they can be stored in sheltered conditions, there is no need to discriminate between spring- or summer-felled timber.

\section{AMERICAN INDIAN STUDIES}

$B$ ULLETIN 136 of the Bureau of American Ethnology (Smithsonian Institution) consists of a further series of six anthropological papers dealing with the American Indian and allied subjects.

Miss Frances Densmore contributes two more papers to her long series on the music of the American Indian. The first deals with the Indians of British Columbia, and is noteworthy as being her first work in Canada. Unlike most of her earlier papers, it deals with many tribes, being the product of a visit to a hopping centre where Indians from widely separated localities were at work. The music of the Choctaw Indians of Mississippi is the subject of the second paper. The investigation was prompted by the discovery that the songs of the Yuma Indians have a definite form, consisting of several periods recurring in regular order, a peculiarity which was afterwards found to occur sporadically among the Pueblos and the Seminoles, and as far away as the Tule Indians of San Blas, Panama. This characteristic, described as "period formation", was found also among the Choctaw, particularly in songs inferred to be ancient. Numerous songs were recorded.

A paper entitled "Ethnological Data concerning. 100 Yucatan Plants", by Morris Steggarda, is based on a collection made by him in the area occupied by the Maya Indians, near Chichen Itza. Having eliminated 125 species, about which the available data had already been published, he prepared this interesting report on the remaining 100 , so the in. formation in it is entirely new. The body of the report consists of a catalogue, arranged in alpha. betical order of scientific names, giving notes on the uses to which each is put by the Maya. This is followed by an alphabetical list of Maya names, and the paper ends with a discussion of the uses of the plants. Some are used, of course, for the production of various necessary objects and ornaments, but the greatest number are employed in the treatment of disease. It appears that the yerbateros, or herb doctors, have little scientific knowledge on which to base their treatments, which are in consequence a mixture of folklore, superstition and herbal concoctions, of which few have any curative value.

Steggarda is also responsible for "A Description of 30 Towns in Yucatan, Mexico", consisting of topo. graphical and historical notes on a selection of the towns and villages he has visited. This should be useful to intending travellers in the area. (The first 